\title{
Effects of Dietary pH and Electrolyte Concentration on Utilization of Crystalline Amino Acids by Fingerling Carp*1
}

\author{
Takeshi MuraI, ${ }^{* 2}$ Yasuhiro Hirasawa, ${ }^{* 3}$ Toshio AkIYAma, ${ }^{* 2}$ \\ and Takeshi NosE*2
}

(Accepted December 13, 1982)

\begin{abstract}
Feeding experiment was conducted for 6 weeks to clarify effects of supplemental electrolyte and/or dietary $\mathrm{pH}$ on utilization of an amino acid diet using fingerling carp. Growth and feed efficiency improved without noticeable effect on feed consumption as the dietary pH was raised from 4.6 to 5.2 or 5.8 together with rise in $\mathrm{Na}$ level from $0.13 \%$ to $1.23 \%$ or $1.73 \%$, due to substitutions of Asp and Glu with $\mathrm{Na} \cdot \mathrm{Asp}$ and $\mathrm{Na} \cdot \mathrm{Glu}$, respectively. Also change in the dietary $\mathrm{pH}$ alone showed the similar effects on the growth and feed efficiency when $\mathrm{pH}$ of the diet was lowered from 4.9 to 4.5 by addition of acetic acid, where Asn and Gln were used instead of Asp and Glu to raise the original dietary $\mathrm{pH}$ to about 6 . When the dietary $\mathrm{pH}$ were kept at 5.7-5.9 levels with use of Asn and Gln instead of Asp and Glu, supplement of $\mathrm{K}(1.41 \%)$ as acetate form up to equimolar level of $\mathrm{Cl}$ from supplemented $\mathrm{Arg} \cdot \mathrm{HCl}$ and Lys $\cdot \mathrm{HCl}$ resulted in better growth and feed efficiency than that of $\mathrm{Na}(0.70 \%)$. However, excess supplements of $\mathrm{K}(2.30 \%)$ and $\mathrm{Na}(1.23 \%)$ depressed growth and feed efficiency almost to half in the former and only slightly in the latter with significantly elevated feed consumption in both cases. Rise in the dietary pH level alone or combination with increment in $\mathrm{Na}$ level resulted in the decline of moisture with increased fat content as well as fall in $\mathrm{Na}, \mathrm{K}$ and ash contents in the whole body of fish sampled at the end of the experiment. However, almost completely opposite results were obtained when $\mathrm{Na}$ or $\mathrm{K}$ level was raised with little change in the dietary $\mathrm{pH}$.
\end{abstract}

Utilization of an amino acid diet by carp has been reported to be very poor. ${ }^{1)}$ NoSE et al. ${ }^{2)}$ found the utilization of the amino acid diet could be improved adjusting the dietary $\mathrm{pH}$ to 5 or higher with an addition of $\mathrm{NaOH}$ solution, which phenomenon has also been recognized in channel catish.s) The metabolism of amino acids is markedly influenced by levels of dietary electrolytes $^{4}$ ) and the transport of amino acids into tissues is often closely associated with $\mathrm{Na}^{+}$and $\mathrm{K}^{+}$transport. $^{\text {s) }}$ Furthermore, ScotT et al. ${ }^{\text {s) }}$ recommend that in purified diets for chicken where the amino acids are added as the hydrochloride forms, approximately equimolar amount of sodium or potassium should be supplied as salts containing metabolizable anions, such as carbonate or acetate.

Therefore, from the results of studies reported by Nose et al. for carp ${ }^{2)}$ and WILSON et al. for channel catfish, ${ }^{8}$ it is impossible to differentiate the effects between dietary $\mathrm{pH}$ and sodium sup- plement as the possible cause for the improved utilization of the $\mathrm{pH}$ adjusted amino acid diets. The present experiment was conducted to clarify effects of dietary $\mathrm{pH}$ and supplement of electrolyte on utilization of crystaline amino acids by carp using acetic acid for $\mathrm{pH}$ adjustment and sodium acetate or potassium acetate as a supplemental electrolyte.

\section{Materials and Methods}

The percentage composition and nutritent content of the test diets are presented in Table 1. The amino acid mixture used in the previous study ${ }^{7)}$ was employed as a nitrogen sourse for diet 1 of which pH was 4.6. About $72 \%$ of both aspartic and glutamic acids in diet 2 were substituted with sodium aspartate and sodium glutamate, respectively, to bring the dietary $\mathrm{pH}$ up to 5.2 and the total substitution was made for diet 3 to raise the dietary $\mathrm{pH}$ to 5.8 . For diets 4-9,

*1 Part of this paper was presented at the annual meeting of the Japanese Society of Scientific Fisheries. Tokyo, April, 1981.

*2 Division of Fish Nutrition, National Research Institute of Aquaculture, Tamaki, Watarai, Mie 510-04,

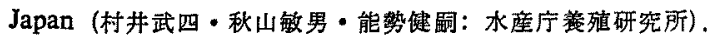

*8 Faculty of Fisheries, Mie University, Edobashi, Tsu, Mie 519, Japan（平澤康弘：三重大学水産学部）。 
Table 1. Percentage composition and proximate analysis $(\%)$ of experimental diets

\begin{tabular}{|c|c|c|c|c|c|c|c|c|c|}
\hline \multirow{2}{*}{ Ingredient and nutrient } & \multicolumn{9}{|c|}{ Diet No. } \\
\hline & 1 & 2 & 3 & 4 & 5 & 6 & 7 & 8 & 9 \\
\hline AA mix $* 1$ & 28.15 & 28.15 & 28.15 & 28.15 & 28.15 & 28.15 & 28.15 & 28.15 & 28.15 \\
\hline Asp & 2.62 & 0.82 & & & & & & & \\
\hline $\mathrm{Asp}_{\mathrm{sp}} \mathrm{Na}$ & & 2.34 & 3.40 & & & & & & \\
\hline $\mathrm{Asn} \cdot \mathrm{H}_{2} \mathrm{O}$ & & & & 2.95 & 2.95 & 2.95 & 2.95 & 2.95 & 2.95 \\
\hline Glu & 7.34 & 2.29 & & & & & & & \\
\hline $\mathrm{Glu} \cdot \mathrm{Na}$ & & 6.42 & 9.34 & & & & & & \\
\hline Gln & & & & 7.29 & 7.29 & 7.29 & 7.29 & 7.29 & 7.29 \\
\hline Dextrin & 30.00 & 30.00 & 30.00 & 30.00 & 30.00 & 30.00 & 30.00 & 30.00 & 30.00 \\
\hline Feed oil & 8.00 & 8.00 & 8.00 & 8.00 & 8.00 & 8.00 & 8.00 & 8.00 & 8.00 \\
\hline Vitamin mixture & 4.00 & 4.00 & 4.00 & 4.00 & 4.00 & 4.00 & 4.00 & 4.00 & 4.00 \\
\hline Mineral mixture & 4.00 & 4.00 & 4.00 & 4.00 & 4.00 & 4.00 & 4.00 & 4.00 & 4.00 \\
\hline $\mathrm{Ca}\left(\mathrm{H}_{2} \mathrm{PO}_{4}\right)_{2} \cdot \mathrm{H}_{2} \mathrm{O}$ & 1.38 & 1.38 & 1.38 & 1.38 & 1.38 & 1.38 & 1.38 & 1.38 & 1.38 \\
\hline $\mathrm{Na} \cdot$ acetate & & & & & & 2.06 & 3.93 & & \\
\hline $\mathrm{K} \cdot$ acctate & & & & & & & & 2.46 & 4.70 \\
\hline Acetic acid & & & & 1.49 & 2.84 & & & & \\
\hline $\mathrm{NH}_{4} \cdot$ acetate & 3.69 & 3.69 & 3.69 & & & & & & \\
\hline $\mathrm{CMC}$ & 5.00 & 5.00 & 5.00 & 5.00 & 5.00 & 5.00 & 5.00 & 5.00 & 5.00 \\
\hline$\alpha$-cell & 5.82 & 3.91 & 3.04 & 7.74 & 6.39 & 7.17 & 5.30 & 6.77 & 4.53 \\
\hline Moisture & 8.33 & 9.46 & 9.74 & 7.60 & 7.70 & 7.96 & 8.67 & 8.12 & 7.91 \\
\hline Crude proteir & 33.4 & 33.1 & 33.0 & 36.5 & 36.5 & 36.1 & 36.0 & 36.0 & 36.2 \\
\hline Crude fat & 6.58 & 6.31 & 6.30 & 6.92 & 7.14 & 6.61 & 6.73 & 6.71 & 6.95 \\
\hline Ash & 3.75 & 6.35 & 7.23 & 3.72 & 3.75 & 4.92 & 6.25 & 5.42 & 7.09 \\
\hline $\mathrm{Na} * 2$ & 0.13 & 1.23 & 1.73 & 0.13 & 0.13 & 0.70 & 1.23 & 0.13 & 0.13 \\
\hline $\mathrm{K}^{* 2}$ & 0.43 & 0.43 & 0.43 & 0.43 & 0.43 & 0.43 & 0.43 & 1.41 & 2.30 \\
\hline $\mathrm{pH}$ & 4.6 & 5.2 & 5.8 & 4.9 & 4.5 & 5.7 & 5.9 & 5.8 & 5.9 \\
\hline
\end{tabular}

aspargine and glutamine were used instead of aspartic and glutamic acids on an equimolar basis to keep high levels of the dietary $\mathrm{pH}(5.7-5.9)$ without additional electrolyte. The $\mathrm{pH}$ of diets 4 and 5 were lowered by adding acetic acid up to the equivalent levels of sodium or potassium acetate in diets 6 or 8 and 7 or 9, respectively. Chloride from arginine and lysine hydrochlorides in diets 6 and 8 were balanced by adding equimolar amounts of sodium and potassium acetates. While, excess amounts of sodium and potassium acetates were supplemented to diets 7 and 9 , respectively, up to equimolar level of sodium in diet 2. The nutrient contents except the experimental variables were kept constant as much as possible by the addition of ammonium acetate and the total volume was brought to $100 \%$ with cellulose. The diets were prepared as previously described. ${ }^{7}$

An initial mean weight of fish which were fullsib of mirror carp was approximately $1.8 \mathrm{~g}$. Feeding experiment was carried out for 6 weeks under the similar conditions reported before. ${ }^{8)}$
At the end of the feeding experiment, 10 fish from each tank (duplicate tanks/treatment) were randomly sampled and the whole carcasses of 10 fish were pooled and were ground to slurry with a homogenizer. Protein, fat, moisture and ash contents of each sample (2 samples/treatment) were determined by the methods described by AkrYama et al. ${ }^{93}$ Determinations of sodium and potassium concentrations in these samples were carried out using a frame spectrophotometer (Shimazu AA-645). Statistical evaluation of the data were performed as previously described.8)

\section{Results and Discussion}

Results of the growth, feed consumption and feed efficiency were summarized in Table 2 . Growth and feed efficiency improved without any substantial effect on feed consumption as the dietary $\mathrm{pH}$ was raised from 4.6 (diet 1) to 5.8 (diet 3) due to the substitution of aspartic and glutamic acids with sodium aspartate and sodium glutamate. These results agreed well with those 
Table 2. Effects of dietary level of $\mathrm{pH}$, sodium and potassium on the growth, feed consumption and feed efficiency of fingerling carp*1 fed the experimental diets for 6 weeks

\begin{tabular}{|c|c|c|c|c|c|}
\hline Diet No. & Treatment $* 2$ & $\begin{array}{l}\text { Avg wt gain*3 } \\
(\mathrm{g})\end{array}$ & $\%$ wt gain & $\begin{array}{c}\text { Feed } \\
\text { consumption*8 } \\
(\% \text { day })\end{array}$ & $\begin{array}{c}\text { Feed } \\
\text { efficiency*3 } \\
(\%)\end{array}$ \\
\hline 1 & $4.6-0.13-0.43$ & $0.65^{\mathrm{a}}$ & 35.4 & $10.5^{\mathrm{abc}}$ & $6.8^{\mathrm{a}}$ \\
\hline 2 & $5.2-1.23-0.43$ & $1.20^{\mathrm{bcd}}$ & 64.7 & $10.0^{\mathrm{ab}}$ & $11.6^{\mathrm{bc}}$ \\
\hline 3 & $5.8-1.73-0.43$ & $1.37^{\mathrm{cda}}$ & 75.7 & $10.5^{\text {abc }}$ & $12.5^{\mathrm{c}}$ \\
\hline 4 & $4.9-0.13-0.43$ & $1.04^{\mathrm{bc}}$ & 55.8 & $11.2^{\mathrm{bc}}$ & $9.3^{\mathrm{ab}}$ \\
\hline 5 & $4.5-0.13-0.43$ & $0.73^{\mathrm{a}}$ & 40.7 & $11.8^{\circ}$ & $6.8^{\mathrm{a}}$ \\
\hline 6 & $5.7-0.70-0.43$ & $1.53^{\circ}$ & 83.6 & $9.3^{\mathrm{a}}$ & $15.2^{d}$ \\
\hline 7 & $5.9-1.23-0.43$ & $1.30^{\mathrm{c} d \mathrm{e}}$ & 72.8 & $11.3^{\mathrm{be}}$ & $11.3^{\mathrm{be}}$ \\
\hline \& & $5.8-0.13-1.41$ & $1.89^{\mathrm{f}}$ & 103.2 & $9.4^{a}$ & $17.3^{d}$ \\
\hline \multirow[t]{2}{*}{9} & $5.9-0.13-2.30$ & $1.01^{\mathrm{b}}$ & 56.2 & $11.3^{\mathrm{bcc}}$ & $9.2^{\mathrm{ab}}$ \\
\hline & Pooled SEM & 0.09 & & 0.45 & 0.77 \\
\hline
\end{tabular}

*1 Initial mean weight was approximately $1.8 \mathrm{~g}$.

*2 Dietary level of measured pH and calculated concentration of sodium and potassium, respectively,

*3 Average values from duplicate tanks containing 20 fish each. Values followed by the same letter are not significantly different $(\mathrm{P}>0.05)$.

obtained by adjusting dietary $\mathrm{pH}$ with $\mathrm{NaOH}$ solution reported for carp ${ }^{2)}$ and channel catfish. ${ }^{3)}$ Also change in the dietary $\mathrm{pH}$ level without altering sodium of potassium concentration (diets 4 and 5) showed the similar effects on the growth and feed efficiency. The study reported by OKUMURA and TASAKI ${ }^{10}$ indicate that the efficiency of nitrogen retention in chickens is significantly influenced by variations in acid-base balance, but the uric acid excretion is not affected by the dietary levels of sodium, potassium and chloride. ${ }^{11}$ Thus, acid-base balance alone may have a marked influence on the synthesis and excretion of end products of nitrogen metabolism as has been suggested by Austic and CALvert. ${ }^{4)}$

Amino acid transport into tissues is also closely associated with $\mathrm{Na}^{+}$and $\mathrm{K}^{+}$transport, ${ }^{3}$ ) but compared with the results from diet 6 or 8 , supplement of sodium (diet 7) or potassium (diet 9) up to equimolar level of sodium in diet 2 depressed growth and feed efficiency with elevated feed consumption when the dietary $\mathrm{pH}$ was 5.9. This results indicate that excess electrolyte may be not only unnecessary, but detrimental if a dietary $\mathrm{pH}$ is sufficiently high. Supplement of potassium (diet 8) up to equimolar level of chloride resulted in significantly better growth and slightly better feed efficiency than that of sodium (diet 6). Thus, approximately equimolar amount of sodium or potassium should be supplied when the amino acids are added as the hydrochlorides ${ }^{3}$ ) even in diet for fish if a dietary $\mathrm{pH}$ is about 6 , and potassium may be superior to sodium for this purpose.

Excess of potassium is reported to be less detrimental than that of sodium for chickens. ${ }^{\theta}$ )
However, the addition of potassium at the level higher than the equimolar level of chloride depressed the growth and feed efficiency of the fish more drastically (almost to half) than that of sodium which depressed only slightly. These phenomena coincided with the results from the study of carp reported by $\mathrm{LEE},{ }^{12)}$ where $\mathrm{KOH}$ and $\mathrm{NaOH}$ were used to adjust the dietary $\mathrm{pH}$ of the amino acid diets.

Data on analysis of the whole body are shown in Table 3. Changes in the body composition reflected those of growth and feed efficiency of the respective dietary treatment. Rise in the dietary pH level alone or combination with increment in supplemental sodium level resulted in decline in moisture with increased fat content, and fall in sodium, potassium and ash contents as well. Like the growth response, almost completely opposite trends were obtained in these body constituents when the dietary $\mathrm{pH}$ were kept at high levels (5.7-5.9) and sodium or potassium level was raised. Only exception for this trend was ash in these groups (diets 6-9), of which contents were significantly higher than those of the former groups (diets 1-5). The dietary treatments showed no appreciable effect on crude protein level of the whole body.

Still more studies are needed for biochemical interpretation for these results, but the body compositions may have changed as the fish grew. Also completely opposite responses of the fish fed diets $1-3$ and diets 6-9 against the electrolyte levels indicate a certain interaction between acidbase balance and level of electrolytes supplemented. That is, level of electrolyte in a diet 
Table 3. Level of moisture, crude protein, crude fat, ash, sodium and potassium contents in the whole body of fish fed the experimental diets for 6 weeks

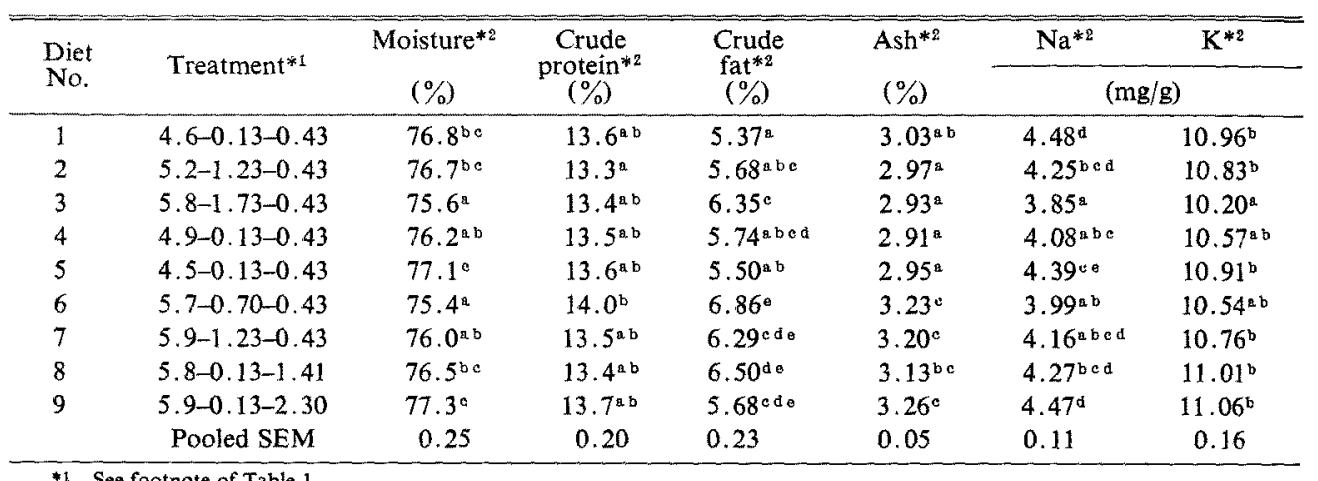

*1 See footnote of Table 1 .

*2 Average values of two samples/treatment (pooled sample of 10 fish/tank). Values followed by the same letter are not significantly different $(P>0.05)$.

may cause different reactions with a change in dietary $\mathrm{pH}$.

These results clearly indicate that dietary $\mathrm{pH}$ and level of dietary electrolytes or combination of both factors play a certain role in amino acid metabolism. However, they are not major factors which are responsible for poor utilization of crystalline amino acids by carp, becuase the best performance in all dietary groups which was obtained by feeding diet 8 , was only $103 \%$ weight gain with less than $20 \%$ of feed efficiency in 6 weeks. Thus, a more thorough study seems to be necessary to clarify a role of electrolytes in amino acid metabolism of fish.

\section{References}

1) H. Aoe, I. Masuda, I. Abe, T. Saito, T. Toyoda, and S. Kitamura: Bull. Japan. Soc. Sci. Fish., 36, 407-413 (1970).
2) T. Nose, S. Arai, D. Lee, and Y. Hashimoto: Bull. Japan. Soc. Sci. Fish, 40, 903-908 (1974).

3) R.P. Wilson, D.E. HaRding, and D.L. GarLING: J. Nutr. 107, 166-170 (1977).

4) R. E. Austic and C.C. Calvert: Federation Proc., 40, 63-67 (1981).

5) H.N. Christensen: Biological Transport. Benjamin, Reading, MA. (1975).

6) M. L. SCOTT, M. C. NESHEIM, and R. J. Young: Nutrition of the Chicken, M.L. Scott \& Associates, N.Y. (1969).

7) T. Murat, T. AkiYama, and T. Nose: Bull. Japan. Soc. Sci. Fish., 48, 787-792 (1982).

8) T. Murat, T. Akiyama, and T. Nose: Bull. Japan. Soc. Sci. Fish., 47, 523-527 (1981).

7) T. Akryama, I. Yagisawa, and T. Nose: Bull. Natl. Res. Inst. Aquaculture, 2, 35-42 (1981).

10) J. I. OKumura and I. TASAKI: J. Nutr., 95, 148-152 (1968).

11) R. E. Austic: Federation Proc., 37, 2865 (1978).

12) D. LEE: MS thesis, University of Tokyo, (1974). 